\title{
Organic matter matters for ice nuclei of agricultural soil origin
}

\author{
Y. Tobo ${ }^{1, *}$, P. J. DeMott ${ }^{1}$, T. C. J. Hill ${ }^{1,2}$, A. J. Prenni ${ }^{1,{ }^{* *}}$, N. G. Swoboda-Colberg ${ }^{3}$, G. D. Franc ${ }^{2, \dagger}$, and \\ S. M. Kreidenweis ${ }^{1}$ \\ ${ }^{1}$ Department of Atmospheric Science, Colorado State University, Fort Collins, CO 80523, USA \\ ${ }^{2}$ Department of Plant Sciences, University of Wyoming, Laramie, WY 82071, USA \\ ${ }^{3}$ Department of Geology and Geophysics, University of Wyoming, Laramie, WY 82071, USA \\ * now at: National Institute of Polar Research, Tachikawa, Tokyo 190-8518, Japan \\ ** now at: Air Resources Division, National Park Service, Lakewood, CO 80225, USA \\ $\dagger$ deceased
}

Correspondence to: Y. Tobo (yutaka.tobo@gmail.com)

Received: 29 March 2014 - Published in Atmos. Chem. Phys. Discuss.: 11 April 2014

Revised: 27 June 2014 - Accepted: 5 July 2014 - Published: 22 August 2014

\begin{abstract}
Heterogeneous ice nucleation is a crucial process for forming ice-containing clouds and subsequent iceinduced precipitation. The importance for ice nucleation by airborne desert soil dusts composed predominantly of minerals is widely acknowledged. However, the potential influence of agricultural soil dusts on ice nucleation has been poorly recognized, despite recent estimates that they may account for up to $20-25 \%$ of the global atmospheric dust load. We have conducted freezing experiments with various dusts, including agricultural soil dusts derived from the largest dustsource region in North America. Here we show evidence for the significant role of soil organic matter (SOM) in particles acting as ice nuclei (IN) under mixed-phase cloud conditions. We find that the ice-nucleating ability of the agricultural soil dusts is similar to that of desert soil dusts, but is clearly reduced after either $\mathrm{H}_{2} \mathrm{O}_{2}$ digestion or dry heating to $300^{\circ} \mathrm{C}$. In addition, based on chemical composition analysis, we demonstrate that organic-rich particles are more important than mineral particles for the ice-nucleating ability of the agricultural soil dusts at temperatures warmer than about $-36^{\circ} \mathrm{C}$. Finally, we suggest that such organic-rich particles of agricultural origin (namely, SOM particles) may contribute significantly to the ubiquity of organic-rich IN in the global atmosphere.
\end{abstract}

\section{Introduction}

It has been shown that certain aerosol particles acting as ice nuclei (IN), such as dust, soot, volcanic ash and biological materials, are required to trigger ice nucleation at temperatures warmer than about $-36^{\circ} \mathrm{C}$ (Pruppacher and Klett, 1997; Szyrmer and Zawadzki, 1997; Hoose and Möhler, 2012; Murray et al., 2012). In particular, laboratory and modeling studies have suggested that desert soil dusts composed predominantly of minerals are the most important IN sources at temperatures between about -36 and $-15^{\circ} \mathrm{C}$ because of their ice-nucleation properties and abundances in the global atmosphere (Hoose et al., 2010; Murray et al., 2012). In the estimates from these studies, the contribution of other dusts (e.g., agricultural soil dusts) to the global atmospheric IN population has not been taken into account. Although a very large uncertainty remains regarding estimates for the contribution of agricultural emissions to the global atmospheric dust load within the range of 0-50\% (Mahowald et al., 2004; Tegen et al., 2004; Forster et al., 2007; Ginoux et al., 2012), the Intergovernmental Panel on Climate Change (IPCC) Fourth Assessment Report (Forster et al., 2007) and a more recent study (Ginoux et al., 2012) suggest 0-20\% and $25 \%$ as reasonable estimates, respectively.

So far, some laboratory experiments with samples immersed in supercooled water have shown that soils having higher contents of organic matter may serve as better sources of IN than clay minerals (Schnell and Vali, 1972; Conen et al., 2011; O’Sullivan et al., 2014). Agricultural soils are 
known to be complex mixtures of minerals, organic matter and so on. However, the chemical composition of individual agricultural soil dust particles capable of nucleating ice has remained uncertain. Also, the focus of these earlier studies has centered on the role of fertile soil dusts as IN at temperatures warmer than about $-15^{\circ} \mathrm{C}$ (Schnell and Vali, 1972; Conen et al., 2011; O'Sullivan et al., 2014), where clay minerals are less effective as IN (Szyrmer and Zawadzki, 1997; Murray et al., 2012).

In this study, we examine heterogeneous ice nucleation by aerosolized agricultural soil dusts under conditions above water saturation at temperatures warmer than about $-36^{\circ} \mathrm{C}$ (i.e., mixed-phase cloud conditions where ice crystals coexist with liquid cloud droplets) and their chemical composition. In particular, we focus on the relative importance of organics (i.e., soil organic matter (SOM)) as nuclei for heterogeneous ice nucleation.

\section{Materials and methods}

Agricultural soil dusts were prepared using surface soils $(0-5 \mathrm{~cm}$ in depth) collected on 17 May 2011 from sugar beet $\left(42.12878^{\circ} \mathrm{N}, 104.39516^{\circ} \mathrm{W}, 1270 \mathrm{~m}\right.$ above mean sea level) and grass/alfalfa fallow $\left(42.12266^{\circ} \mathrm{N}, 104.38585^{\circ} \mathrm{W}\right.$, $1270 \mathrm{~m}$ above mean sea level) fields at the Sustainable Agricultural Research and Extension Center (SAREC) near Lingle (mean annual temperature: $9.3^{\circ} \mathrm{C}$ ), Wyoming, USA. The agricultural fields are located within the largest dust-source region in North America (Ginoux et al., 2012). Soil samples were air dried on an aluminum tray in clean conditions and then divided into particles smaller than $45 \mu \mathrm{m}$ by dry sieving. As a reference for natural desert soil dusts, we used China loess soils (CJ-1) (Nishikawa et al., 2000), which were collected in an arid area in Gansu Province, China. We also used the Clay Minerals Society kaolinite (KGa-1b) (Chipera and Bish, 2001; Murray et al., 2011), for comparison. In addition to the untreated samples, we prepared samples treated with $\mathrm{H}_{2} \mathrm{O}_{2}$ and others heated to $300^{\circ} \mathrm{C}$. The former samples were prepared by boiling gently in a $30 \% \mathrm{H}_{2} \mathrm{O}_{2}$ solution until almost all organic matter was expected to be digested (i.e., until no visible reaction could be detected by addition of more $\mathrm{H}_{2} \mathrm{O}_{2}$ ), followed by rinsing with deionized water and drying. The latter samples were prepared by exposing to dry heat at $300{ }^{\circ} \mathrm{C}$ for about $2 \mathrm{~h}$ in a muffle furnace.

The overview of the setup for the freezing experiment system is illustrated in Fig. 1. Dry dust particles were generated using a self-built flask dust generator (nitrogen flow for dust generation: $\sim 2 \mathrm{~L} \mathrm{~min}^{-1}$ ) and then passed through a cyclone (cut-point diameter: $3.5 \mu \mathrm{m}$ at $2 \mathrm{~L} \mathrm{~min}^{-1}$ ) and ${ }^{210} \mathrm{Po}$ neutralizers. It has been reported that while the numbersize distributions of airborne soil dust particles vary depending on the source-area conditions (e.g., surface wind speed, and soil characteristics) and long-range transport regimes, the mode diameters during their long-range transport typi-

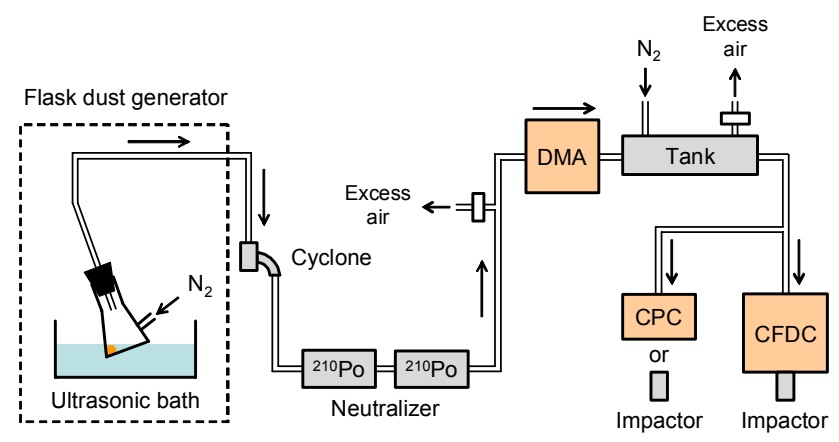

Figure 1. Schematics of the freezing experiment system. Dry dust particles were generated from the flask dust generator. The DMA selected particles with a mobility diameter of $600 \mathrm{~nm}$ for analysis by the CPC and CFDC. Impactors were used for direct sampling of the total particles and ice-nucleating particles.

cally range from $\sim 2 \mu \mathrm{m}$ down to submicrometers (Formenti et al., 2011; Kok, 2011). Here, we prepared particles with a mobility diameter of $600 \mathrm{~nm}$ selected in a differential mobility analyzer (DMA; Model 3081, TSI Inc.; sheath flow: 4.5 $\mathrm{L} \mathrm{min}^{-1}$, sample flow: $\left.1 \mathrm{~L} \mathrm{~min}^{-1}\right)$. A condensation particle counter (CPC; Model 3010, TSI Inc.) was used to measure number concentrations of the total dust aerosol particles. A Colorado State University continuous flow diffusion chamber (CFDC; Rogers et al., 2001; sheath flow: $8.5 \mathrm{~L} \mathrm{~min}^{-1}$, sample flow: $1.5 \mathrm{~L} \mathrm{~min}^{-1}$ ) was used to measure number concentrations of IN active under conditions above water saturation $(105.0 \pm 0.5 \%$ relative humidity with respect to liquid water) at temperatures warmer than about $-36^{\circ} \mathrm{C}$. Under such conditions, heterogeneous ice-nucleation processes including deposition nucleation (ice formation on the surfaces of insoluble nuclei from ice-supersaturated water vapor) and condensation/immersion freezing (ice formation during or following the condensation growth of aqueous droplets containing insoluble nuclei) are expected to be activated (Sullivan et al., 2010a, b; Tobo et al., 2012; Wex et al., 2014). In particular, we expect the predominance of immersion freezing in this regime, since the relative humidity is high enough to activate cloud droplet formation. Following such a particle nucleation/growth section, the CFDC has a droplet evaporation section where only ice saturation exists. Since cloud droplets cannot survive though the evaporation section unless the relative humidity with respect to liquid water in the particle nucleation/growth section exceeds $\sim 108 \%$ (Sullivan et al., 2010a, b), only particles that form ice crystals are counted as IN with an optical particle counter at the outlet. The IN data were collected every second and then averaged for $150-180 \mathrm{~s}$. The total dust aerosol particles and IN active at given temperatures were collected on a Butvar film supported by Ni mesh grids (EM Japan Co., Ltd.) using impactors. The dust aerosol particles were collected using a two-stage jet impactor (Matsuki et al., 2010a, b; Tobo et al., 2010). We used only the second stage of the impactor, 
because the $50 \%$ cutoff aerodynamic diameters of the first and second stages at a sample flow of $1 \mathrm{~L} \mathrm{~min}^{-1}$ are estimated to be 1.6 and $0.2 \mu \mathrm{m}$, respectively, and the mobility diameter of the particles is $600 \mathrm{~nm}$ (i.e., $0.6 \mu \mathrm{m}$ ). For the IN sampling, the particles that nucleated ice and were grown to ice crystal sizes were collected using a single-jet impactor (Prenni et al., 2013; Tobo et al., 2013) installed at the outlet of the CFDC. The $50 \%$ cutoff aerodynamic diameter at a sample flow of $1.5 \mathrm{~L} \mathrm{~min}^{-1}$ is estimated to be $2.9 \mu \mathrm{m}$. The size, morphology and elemental composition of the individual collected particles were analyzed manually after Au coating (coating thickness: 2-3 nm) using a Quanta FEG MK2 scanning electron microscope (SEM; FEI Company) combined with an energy dispersive X-ray analyzer (EDX; Model 51-XMX0005, Oxford Instruments America Inc.). After the SEM images of individual particles were taken, the X-ray spectra from the particles were acquired for $20 \mathrm{~s}$ of live time at an acceleration voltage of $20 \mathrm{kV}$.

\section{Results and discussion}

\subsection{Freezing experiments}

In Fig. 2a, we show the number fraction of particles capable of nucleating ice as a function of temperature. The results show that the ice-nucleation properties of agricultural soil dusts obtained from sugar beet and grass/alfalfa fallow fields in Wyoming are similar to each other. Treatment with $\mathrm{H}_{2} \mathrm{O}_{2}$ is a commonly used technique to oxidize organic matter from soils and to obtain the remaining minerals (Conen et al., 2011; O'Sullivan et al., 2014). After $\mathrm{H}_{2} \mathrm{O}_{2}$ treatment, both agricultural soil dusts experienced a significant reduction in their ice-nucleating ability at temperatures warmer than about $-36^{\circ} \mathrm{C}$, suggesting that they contain specific icenucleation active constituents that can be removed by $\mathrm{H}_{2} \mathrm{O}_{2}$ treatment (most likely, organic matter). To evaluate the possibility that the ice-nucleation properties of some mineral components might be affected by $\mathrm{H}_{2} \mathrm{O}_{2}$ treatment, we conducted freezing experiments with China loess soil dust (desert loess; a proxy for Asian natural desert soil dusts; Nishikawa et al., 2000) and kaolinite (Chipera and Bish, 2001) in the same manner. The results indicate that the impact of $\mathrm{H}_{2} \mathrm{O}_{2}$ treatment on their ice-nucleating ability is relatively small (within the range of error). Dry heating is also known as a technique to remove and/or deactivate organic matter in soils. For example, Fernández et al. (1997) reported that soils heated at $150{ }^{\circ} \mathrm{C}$ exhibit no significant loss of organic matter, whereas those heated at $490^{\circ} \mathrm{C}$ lose almost all the organic matter. As for the ice-nucleation properties, we confirmed that dry heating to $300^{\circ} \mathrm{C}$ has a similar impact to $\mathrm{H}_{2} \mathrm{O}_{2}$ digestion (Fig. 3).

In Fig. 2b, we compare the experimental data for agricultural soil dusts collected in Wyoming with the parameterizations for various dusts based on the number of ice-nucleation active sites per unit surface area (i.e., ice-nucleation ac-
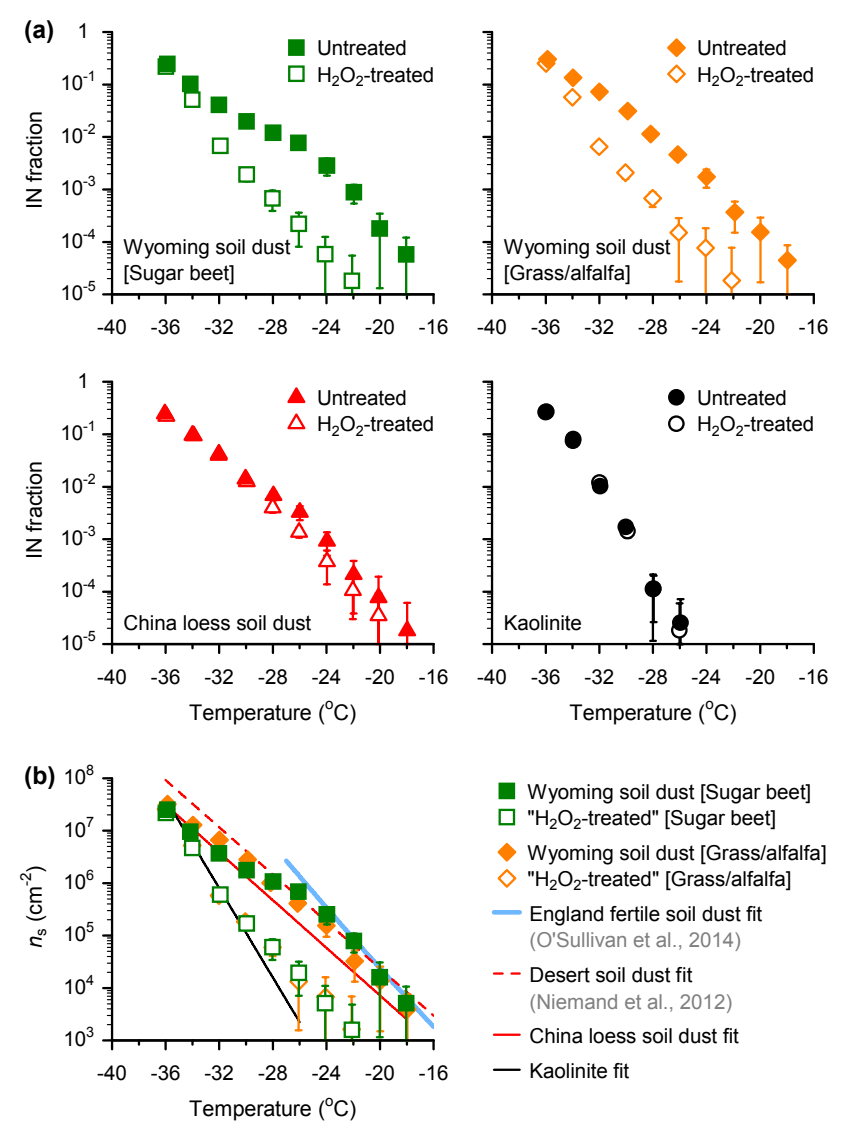

Figure 2. Ice-nucleating ability for various dusts under mixedphase cloud conditions. (a) Fraction of $600 \mathrm{~nm}$ particles capable of nucleating ice. The data for untreated and $\mathrm{H}_{2} \mathrm{O}_{2}$-treated samples are shown in each figure. (b) Ice-nucleation active site densities for various dusts. The $n_{\mathrm{s}}$ parameterizations for various dusts are compared with the data for agricultural soil dusts (before and after $\mathrm{H}_{2} \mathrm{O}_{2}$ treatment) collected in Wyoming. The $n_{\mathrm{s}}$ parameterizations for China loess soil dust and kaolinite are based on the data presented in Fig. A1a. The $n_{\mathrm{s}}$ parameterizations for fertile soil dusts collected in England (O'Sullivan et al., 2014) and desert soil dusts (Niemand et al., 2012) are also shown. Error bars represent standard deviations.

tive site density: $n_{\mathrm{s}}$ ). Their surface area is estimated assuming that all particles are spherical (the $n_{\mathrm{s}}$ parameterizations for the samples presented in Fig. 2a are summarized in Fig. A1a). The results show that the $n_{\mathrm{s}}$ values for the original Wyoming agricultural soil dusts are relatively similar to those for desert and agricultural soil dusts from various locations in the world, at least in the temperature range examined. After $\mathrm{H}_{2} \mathrm{O}_{2}$ digestion, however, the $n_{\mathrm{s}}$ values for the Wyoming agricultural soil dusts are reduced to an almost comparable level to those for kaolinite. Note that the $n_{\mathrm{s}}$ values for the kaolinite presented here are relatively similar to those reported by Murray et al. (2011) and Wex et al. (2014), but are more than one order of magnitude lower than those reported by Kanji et al. (2013) at temperatures warmer than about 

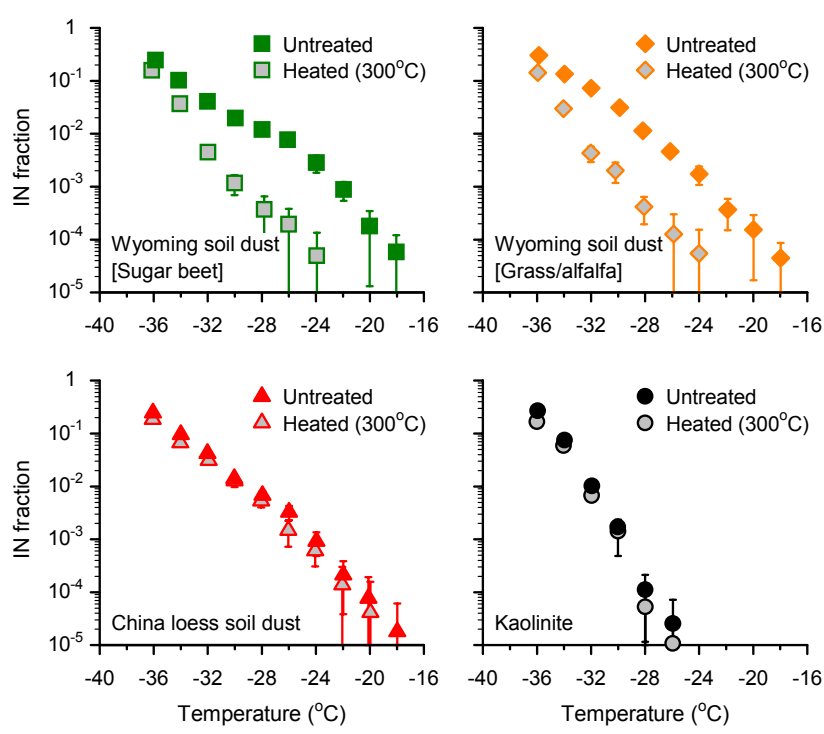

Figure 3. Same as Fig. 2a, but for the data for untreated and heated samples.

$-30^{\circ} \mathrm{C}$ despite the use of the same Clay Minerals Society kaolinite (Fig. A1b). The difference may be related to different experimental techniques and/or application of the particles of different size ranges (e.g., mono- vs. poly-disperse particles); however, further speculation concerning this issue is beyond the remit of this study and is not pertinent to the major conclusions drawn from the comparison of our experimental results obtained using the CFDC. Around $-36^{\circ} \mathrm{C}$ (near to the limit for homogeneous freezing temperature of water in droplets; Koop et al., 2000), all samples presented here show relatively similar $n_{\mathrm{S}}$ values.

\subsection{Identification of particle types}

To identify particle types in the agricultural soil dusts used here, we examined the elemental composition of individual particles using SEM/EDX analysis. A major difficulty in the EDX analysis of submicron particles is their high transparency for the primary electron beam (Laskin and Cowin, 2001). Since the electron beam penetrates the entire particle, the EDX spectrum from the particle projection area contains the background signal from the Butvar film supported by $\mathrm{Ni}$ mesh grids as well as the signal of the particle coated with $\mathrm{Au}$. For this reason, as illustrated in Fig. 4, we compare the EDX spectrum of the particle projection area with that from the particle-free area (i.e., background signal). We found that the majority of the analyzed particles can be classified as either "organics" or "minerals". The major elements of particles categorized as organics are $\mathrm{C}, \mathrm{N}$ and $\mathrm{S}$ (e.g., Fig. 4a, b; some of the elements found in smaller amounts: $\mathrm{O}, \mathrm{F}, \mathrm{Na}, \mathrm{Cl}$ and $\mathrm{K}$ ). It has long been known that SOM serves as a reservoir of nutrients, such as N, P and S (Paul, 2007). As for the samples analyzed here, all the particles categorized as organ-
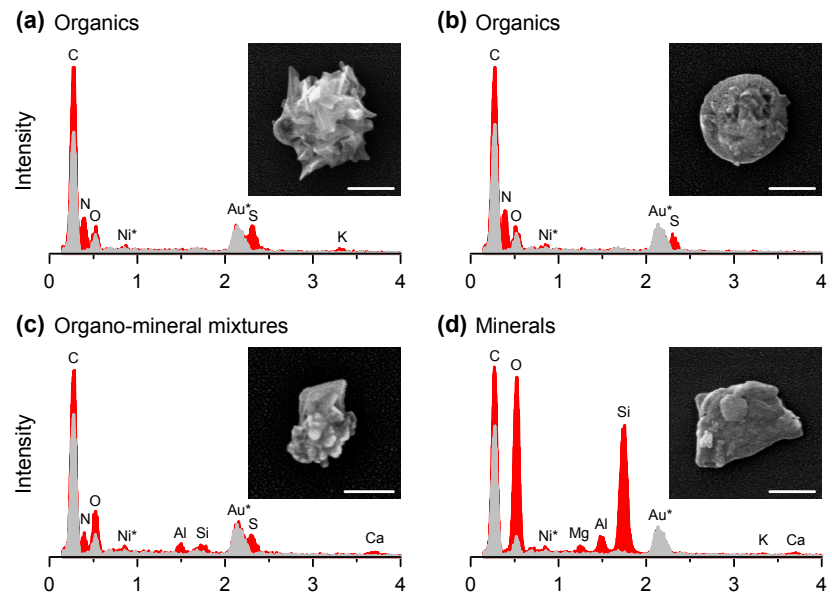

(d) Minerals

(e) Possible soot (categorized as "others")
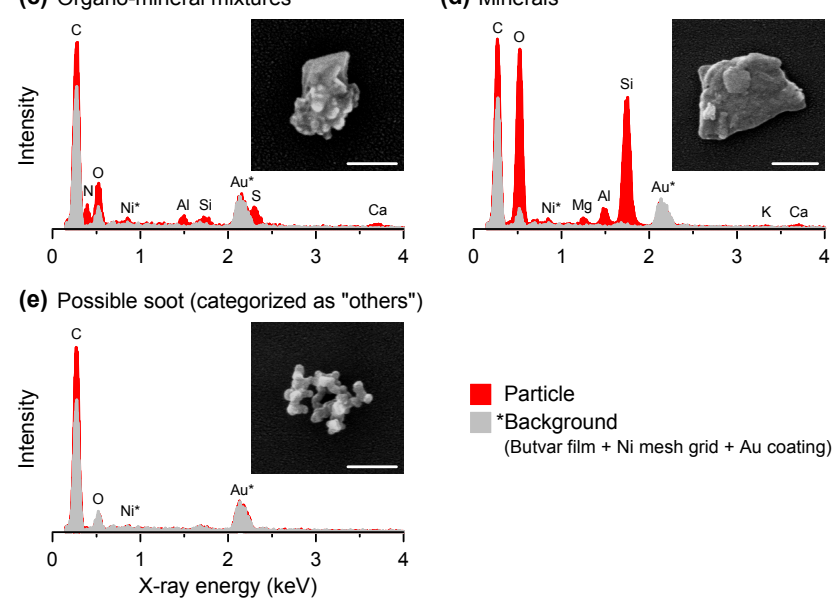

Particle

*Background

(Butvar film + Ni mesh grid + Au coating)

Figure 4. Exemplary SEM/EDX images of sugar beet soil dust particles. (a) Organic particle (crystalline-shape type). (b) Organic particle (amorphous-shape type). (c) Organo-mineral mixture particle. (d) Mineral particle. (e) Soot-like particle. The SEM/EDX images were acquired after Au coating. Scale bars, $300 \mathrm{~nm}$. Red X-ray spectra show the elemental composition of each particle, and grey X-ray spectra represent the background signal caused by a Butvar film supported by Ni mesh grids and Au coating.

ics contained both $\mathrm{N}$ and $\mathrm{S}$, but $\mathrm{P}$ was not found. It should also be noted that we classify carbonaceous particles lacking $\mathrm{N}$ and S (e.g., soot-like particles as shown in Fig. 4e) as "others" and not organics. The major element of particles categorized as minerals is $\mathrm{Si}$ (e.g., Fig. $4 \mathrm{~d}$; some of the elements found in smaller amounts: $\mathrm{C}, \mathrm{O}, \mathrm{F}, \mathrm{Na}, \mathrm{Mg}, \mathrm{Al}, \mathrm{Cl}, \mathrm{K}, \mathrm{Ca}$, $\mathrm{Mn}, \mathrm{Fe}$ and $\mathrm{Ti}$ ). We consider that the detection of the $\mathrm{C}$ peak in particles categorized as minerals may be attributable to the presence of carbonates (e.g., $\mathrm{CaCO}_{3}$ and $\mathrm{CaMg}\left(\mathrm{CO}_{3}\right)_{2}$ ). In this study, only particles containing the major elements of both organics and minerals (i.e., $\mathrm{C}, \mathrm{N}, \mathrm{Si}$ and $\mathrm{S}$ ) are categorized as "organo-mineral mixtures" (e.g., Fig. 4c). Therefore, the possibility remains that Si-rich particles containing $\mathrm{N}$ - and S-free organics or very small amounts of organics are categorized as minerals and not organo-mineral mixtures.

In Fig. 5a, we summarize the results of SEM/EDX analysis for the total dust aerosol particles $(n=95)$ and IN active at temperatures of $-36,-30$ and $-24^{\circ} \mathrm{C}(n=58,52$ and 68 ) in the untreated agricultural soil dust particles. The results show that mineral particles account for more than half of the total dust aerosol population and organic-rich particles for about $40 \%$. However, the number fraction of mineral 
(a)
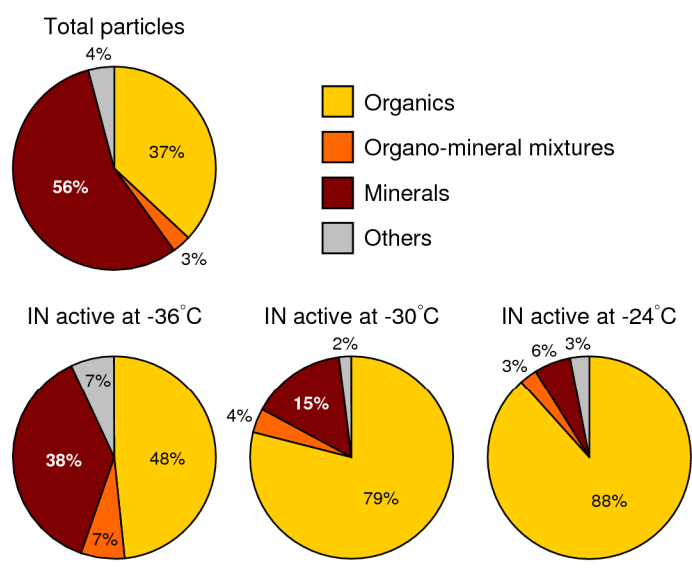

(b) Estimate
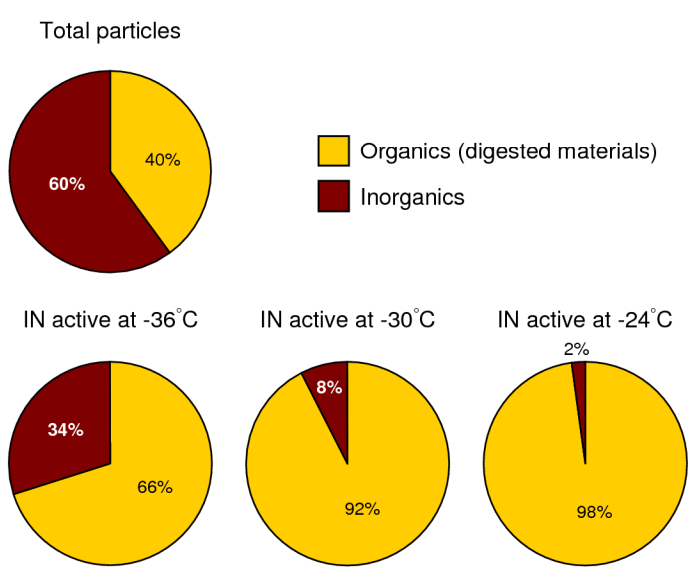

Figure 5. Relative contributions of different particle types to agricultural soil dusts. (a) Compositions of the total dust aerosol particles $(n=95)$ and IN active at $-36,-30$ and $-24{ }^{\circ} \mathrm{C}(n=58,52$ and 68) determined by SEM/EDX analysis. Untreated sugar beat soil dust particles are used. (b) Compositions of the IN active at $-36,-30$ and $-24{ }^{\circ} \mathrm{C}$ estimated from the freezing experiments with untreated and $\mathrm{H}_{2} \mathrm{O}_{2}$-treated agricultural soil dusts. In this calculation, the percentages of organic and inorganic particles in the total dust aerosol particles are set to 40 and $60 \%$, respectively, and then the $n_{\mathrm{s}}$ parameterizations presented in Fig. A1a are used to estimate the number fractions of organic and inorganic IN.

particles in the IN population decreases dramatically with increasing freezing temperatures. Correspondingly, the fraction of organic-rich particles increases, accounting for nearly $90 \%$ of the IN population at around $-24^{\circ} \mathrm{C}$. The fraction of organo-mineral mixture particles or other particles (mainly, soot-like and/or Na-rich particles) is only $2-7 \%$ in both the total dust aerosol and IN populations.

Furthermore, we estimated the fractions of organic and inorganic particles in the agricultural soil dust IN, based on the results of freezing experiments with the soil dusts before and after $\mathrm{H}_{2} \mathrm{O}_{2}$ treatment. Here, we assume that organic and inorganic particles account for 40 and $60 \%$ of the total agricultural dust aerosol particles, respectively (this assumption is based on the results of the SEM/EDX analysis), and that all organic compounds can be digested and removed via $\mathrm{H}_{2} \mathrm{O}_{2}$ treatment, but inorganic components are not altered by $\mathrm{H}_{2} \mathrm{O}_{2}$ treatment. The calculation method is detailed in Appendix A1. The temperature-dependent changes in the fractions of organic and inorganic IN estimated from this calculation (Fig. 5b) are roughly consistent with the results from the $\mathrm{SEM} / \mathrm{EDX}$ analysis (Fig. 5a). If $\mathrm{H}_{2} \mathrm{O}_{2}$ treatment can cause a certain reduction in the ice-nucleating ability of inorganic components, the possibility remains that the results in Fig. $5 \mathrm{~b}$ may somewhat overestimate the fractions of organic IN. We have not exhaustively analyzed the influence of $\mathrm{H}_{2} \mathrm{O}_{2}$ treatment on all known minerals that may be present in the soil dusts. Nevertheless, the results presented here indicate that the reduction of the ice-nucleating ability of the agricultural soil dusts after $\mathrm{H}_{2} \mathrm{O}_{2}$ treatment (Fig. 2) can be explained mainly by the removal of organic matter.

Based on these results, we propose organic-rich particles (namely, SOM particles) as the most important component of agricultural soil dusts for ice nucleation in the temperature regime examined. We note that while phosphorus is known to be one of the major biological markers (Pósfai et al., 2003; Pratt et al., 2009; Creamean et al., 2013; Cziczo et al., 2013), no P-containing particles were found in all of the analyzed particles. This may suggest that there was no measurable contribution of microorganisms (e.g., bacteria and fungal spores) to the numbers of the agricultural soil dusts or IN examined here, although the possibility of the presence of some P-free microorganisms or plants (or their fragments) cannot be ruled out. Organic matter in soils is composed of a variety of macromolecules, such as lignin, cellulose, hemicellulose, protein, lipids, humic-like substances (e.g., humic acid and fulvic acid) and so on (Paul, 2007). So far, freezing experiments with certain standard humic-like substances have indicated that while they can act as IN under mixed-phase cloud conditions (Fornea et al., 2009; Wang and Knopf, 2011; Knopf and Alpert, 2013; Rigg et al., 2013; O'Sullivan et al., 2014), they are much less effective as IN than fertile soil dusts (O'Sullivan et al., 2014). Although the potential importance of ice nucleation by other macromolecules like protein (Hartmann et al., 2013), cellulose (Hiranuma et al., 2014) or fragments of pollen grains (Pummer et al., 2012; Augustin et al., 2013) under mixed-phase cloud conditions has also been suggested, it still remains unclear what materials are responsible for the major source of SOM particles having very high ice-nucleating ability.

It is noteworthy that although agricultural soil dusts collected in Wyoming have similar ice-nucleating abilities to those collected in England (Fig. 2b), the major component responsible for ice nucleation at temperatures between about -36 and $-15^{\circ} \mathrm{C}$ has been interpreted in different ways. Our results demonstrate that the presence of organic compounds (i.e., SOM particles) has a significant influence on 
the ice-nucleating ability of the Wyoming soil dusts throughout the entire temperature range down to $-36^{\circ} \mathrm{C}$. In contrast, O'Sullivan et al. (2014) suggested that mineral components are more important than biogenic components for the icenucleating ability of the England soil dusts at temperatures colder than about $-15^{\circ} \mathrm{C}$. The suggestion by O'Sullivan et al. (2014) was based on the results from freezing experiments with the soil dusts before and after wet heating to $90^{\circ} \mathrm{C}$. It is expected that wet heating to $90-100^{\circ} \mathrm{C}$ deactivates only certain organic matter (e.g., heat-sensitive proteins or proteinaceous compounds; Christner et al., 2008). In fact, it has been reported that wet heating to $90-100^{\circ} \mathrm{C}$ is less effective than $\mathrm{H}_{2} \mathrm{O}_{2}$ digestion in reducing the ice-nucleating ability of fertile soil dusts (Conen et al., 2011; O'Sullivan et al., 2014). In this study, we applied treatments designed to remove and/or deactivate almost all organic matter (i.e., $\mathrm{H}_{2} \mathrm{O}_{2}$ digestion or dry heating to $300^{\circ} \mathrm{C}$ ). Thus, although the possibility remains that the soil dusts from Wyoming and England are very different in composition, we speculate that the different interpretations of the major component responsible for ice nucleation are in part attributable to the different experimental approaches.

Our results also indicate that agricultural and desert soil dusts have similar ice-nucleating abilities and are more efficient IN than kaolinite over the wide temperature range examined (Fig. 2b). However, since treatments to remove and/or deactivate organic matter have a small impact on the ice-nucleating ability of China loess soil dust (a proxy for natural desert soil dusts), the key ice-nucleation active sites contained in desert soil dusts are presumed to be related to inorganic compounds. In this regard, a recent study reported that the feldspar (in particular, $\mathrm{K}$ feldspar) component can explain higher $n_{\mathrm{s}}$ values for desert soil dusts than clay minerals (Atkinson et al., 2013). It is likely that the icenucleating ability of the feldspar component is resistant to $\mathrm{H}_{2} \mathrm{O}_{2}$ treatment (O'Sullivan et al., 2014). It may also be important to note that dust-productive soils in China tend to have much higher contents of feldspar than those in North America (Nickovic et al., 2012). Since we have not evaluated the feldspar content in dust samples used here, further investigations are required to verify the hypothesis concerning the contribution of the feldspar component to their icenucleating abilities. Nevertheless, our results clearly demonstrate that the key IN type is quite different between agricultural and desert soil dusts.

\subsection{Atmospheric implications}

In order to estimate the contribution of agricultural soil dusts to the IN population in the atmosphere, we combined a global simulation of atmospheric concentrations of different aerosol particle types at the $600 \mathrm{hPa}$ pressure altitude (Hoose et al., 2010; Murray et al., 2012) with experimentally derived $n_{\text {S }}$ values. The calculation method for potential IN number concentrations is detailed in Appendix A2. The $n_{\mathrm{S}}$ values used in the calculation are based on the parameterizations for desert soil dusts (Niemand et al., 2012) and for agricultural soil dusts derived from this study. In Fig. 6a, we show the estimates of potential number concentrations of soil dust IN, based on the classical view that all dusts are of desert origin (Murray et al., 2012). In addition, we provide the estimates of potential number concentrations of soil dust IN by assuming that agricultural soil dusts account for either 5 (Tegen et al., 2004) or $25 \%$ (Ginoux et al., 2012) of the total soil dust emissions (Fig. 6b). In these cases, agricultural soil dusts represent a relatively small but nonnegligible contribution to the IN population, as compared with desert soil dusts. Given the results of immersion freezing experiments showing that soils having higher contents of organic matter can serve as efficient IN even at temperatures warmer than about $-15^{\circ} \mathrm{C}$ (Schnell and Vali, 1972; Conen et al., 2011; Hill et al., 2013; O'Sullivan et al., 2014), the contribution of agricultural soil dusts to the IN population at these temperatures may exceed that of desert soil dusts (not shown here). The influence of biological IN on ice clouds is also a controversial topic (Pratt et al., 2009; Creamean et al., 2013; Cziczo et al., 2013). In this regard, the results in Fig. 6b suggest that the contribution of agricultural soil dusts to the IN population may be more significant than that of microorganisms, as exemplified by certain well-known fungal spores (Iannone et al., 2011; Murray et al., 2012), at least at temperatures below about $-18^{\circ} \mathrm{C}$ and on a global scale (however, further studies will be necessary to understand the contribution of various other microorganisms or their fragments). Considering that SOM particles play the dominant role in the ice-nucleating ability of agricultural soil dusts at temperatures warmer than about $-36{ }^{\circ} \mathrm{C}$ (Fig. 5), the results in Fig. 6b suggest the possibility that SOM particles of agricultural origin may contribute strongly to the global atmospheric IN population.

The results presented here offer a possible explanation for the presence of organic-rich particles found in residues within ice clouds and ice-phase precipitation. For example, previous field studies have indicated that organic/sulfate/nitrate particles account for about $5-25 \%$ of the nuclei involved in heterogeneous ice nucleation in icecontaining clouds, whereas mineral particles always predominate (DeMott et al., 2003; Richardson et al., 2007; Pratt et al.., 2009; Creamean et al., 2013; Cziczo et al., 2013). Previous field studies have also pointed out the possibility of heterogeneous ice nucleation by urban anthropogenic organic particles at temperatures as warm as $-20^{\circ} \mathrm{C}$ (Knopf et al., 2010; Wang et al., 2012b), although the composition of individual IN has not been examined. It has been suggested that certain sulfates (e.g., ammonium sulfate) and oxidized organics exist as anhydrous salts or glassy solids at relatively cold temperatures and hence act as effective IN (Abbatt et al., 2006; Murray et al., 2010; Wang et al., 2012a). However, this theory cannot readily explain heterogeneous ice nucleation at temperatures warmer than about $-30^{\circ} \mathrm{C}$ (Abbatt et al., 2006; Murray et al., 2010; Wang et al., 2012a). Here, we peculate 

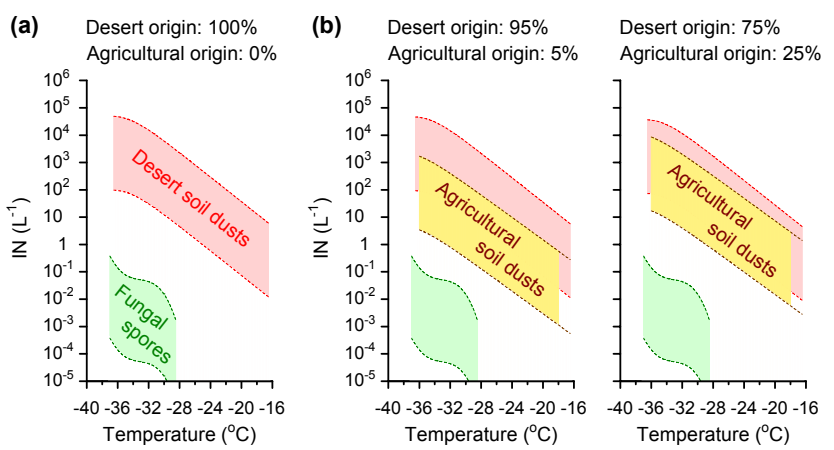

Figure 6. Estimates of global mean number concentrations of IN active under mixed-phase cloud conditions. (a) IN number concentrations for soil dusts, assuming that all dusts are of desert origin. (b) IN number concentrations for desert and agricultural soil dusts, assuming that 5 and $25 \%$ of all dusts are of agricultural origin. Calculations are performed using the $n_{\mathrm{s}}$ parameterizations for desert soil dusts (Niemand et al., 2012) and for untreated agricultural soil dusts (Fig. A1a) and the range of the zonal annual mean concentrations of dusts at $600 \mathrm{hPa}$ (lower and upper limits) (Hoose et al., 2010; Murray et al., 2012). Also provided for comparison are IN number concentrations for fungal spores estimated using the $n_{\mathrm{S}}$ parameterization for Cladosporium spores (Iannone et al., 2011; Murray et al., 2012) and the range of the zonal mean concentrations of fungal spores at $600 \mathrm{hPa}$ (lower and upper limits) (Hoose et al., 2010; Murray et al., 2012).

that SOM particles of agricultural origin can be regarded as a possible source for the organic/nitrate/sulfate particles found in residues within ice clouds. This idea may also be supported by recent work showing that most organic matter contained in hailstones originated from soils (Šantl-Temkiv et al., 2013), leading to speculation that SOM particles might participate in ice nucleation as well as be scavenged by icephase precipitation. Further field, laboratory and modeling studies will therefore be necessary to validate the hypothesis that SOM particles of agricultural origin are indeed an important source of nuclei for atmospheric ice nucleation.

\section{Conclusions}

In this study, we highlight the role of agricultural soil dusts as IN under mixed-phase cloud conditions. Our results indicate that the ice-nucleating ability of agricultural soil dusts is comparable to that of desert soil dusts, but is reduced to almost the same level as clay minerals after treatments to remove and/or deactivate almost all organic matter (i.e., $\mathrm{H}_{2} \mathrm{O}_{2}$ digestion or dry heating to $300^{\circ} \mathrm{C}$ ). Based on chemical composition analysis of individual IN, we demonstrate that the presence of SOM particles, rather than mineral particles, is largely responsible for the ice-nucleating ability of the agricultural soil dusts at temperatures warmer than about $-36^{\circ} \mathrm{C}$. In addition, we suggest the possibility that SOM particles of agricultural origin may be regarded as a possible significant source influencing the ubiquity of organic-rich IN and also residues found within ice clouds and ice-phase precipitation.

\section{Appendix A}

\section{A1 Estimation of the composition of ice nuclei of agricultural soil origin}

Here, we explain how to estimate the fraction of organic and inorganic IN of agricultural soil origin as shown in Fig. 5b, based on the $n_{\mathrm{s}}$ parameterizations obtained from freezing experiments. The number concentration of IN active at a given temperature $T, N_{\mathrm{IN}}(T)$, can be described as (Murray et al., 2012)

$N_{\mathrm{IN}}(T)=N_{\text {total }}\left(1-\exp \left(-n_{\mathrm{s}}(T) s\right)\right)$,

where $N_{\text {total }}$ is the number concentration of total particles, $n_{\mathrm{S}}(T)$ is the ice-nucleation active site density and $s$ is the surface area of a single particle. Similarly, the number concentrations of IN of agricultural soil origin, $N_{\text {IN [agri. soil dust] }}(T)$, can be expressed as

$$
\begin{gathered}
N_{\text {IN [agri. soil dust] }}(T)=N_{\text {total [agri. soil dust] }} \\
\quad\left(1-\exp \left(-n_{\mathrm{S} \text { [agri. soil dust] }}(T) s\right)\right),
\end{gathered}
$$

where $N_{\text {total [agri. soil dust] }}$ is the number concentration of agricultural soil dust particles, and $n_{\mathrm{S}}$ [agri. soil dust] $(T)$ is the $n_{\mathrm{S}}$ value for untreated agricultural soil dust particles presented in Fig. A1a. When calculating $s$, all soil dust particles are assumed to be spherical particles having a diameter of $600 \mathrm{~nm}$. Also, if only inorganic particles exist after the removal of organic matter by $\mathrm{H}_{2} \mathrm{O}_{2}$ treatment, the number concentration of inorganic IN of agricultural soil origin, $N_{\text {IN [inorganic] }}(T)$, can be expressed as

$$
\begin{gathered}
N_{\text {IN [inorganic] }}(T)=N_{\text {total [inorganic] }} \\
\quad\left(1-\exp \left(-n_{\mathrm{S} \text { [inorganic] }}(T) s\right)\right),
\end{gathered}
$$

where $N_{\text {total [inorganic] }}$ is the number concentration of inorganic particles of agricultural soil origin, and $n_{\mathrm{S}}$ [inorganic] is the $n_{\mathrm{s}}$ value for $\mathrm{H}_{2} \mathrm{O}_{2}$-treated agricultural soil dust particles presented in Fig. A1a. To obtain $N_{\text {total [inorganic] }}(T)$ in Eq. (A3), we assume that inorganic (mostly, mineral) particles account for $60 \%$ of the total agricultural soil dust particles (i.e., organic : inorganic ratio $=4: 6$; see the top-left pie chart in Fig. 5b), with the choice of the ratio guided by in the elemental composition analysis of individual $600 \mathrm{~nm}$ particles from the total population (i.e., the top-left pie chart in Fig. 5a):

$N_{\text {total [inorganic] }}=0.6 N_{\text {total [agri. soil dust] }}$.

By combining Eqs. (A2), (A3) and (A4), the fractions of both inorganic and organic particles in the agricultural soil dust 

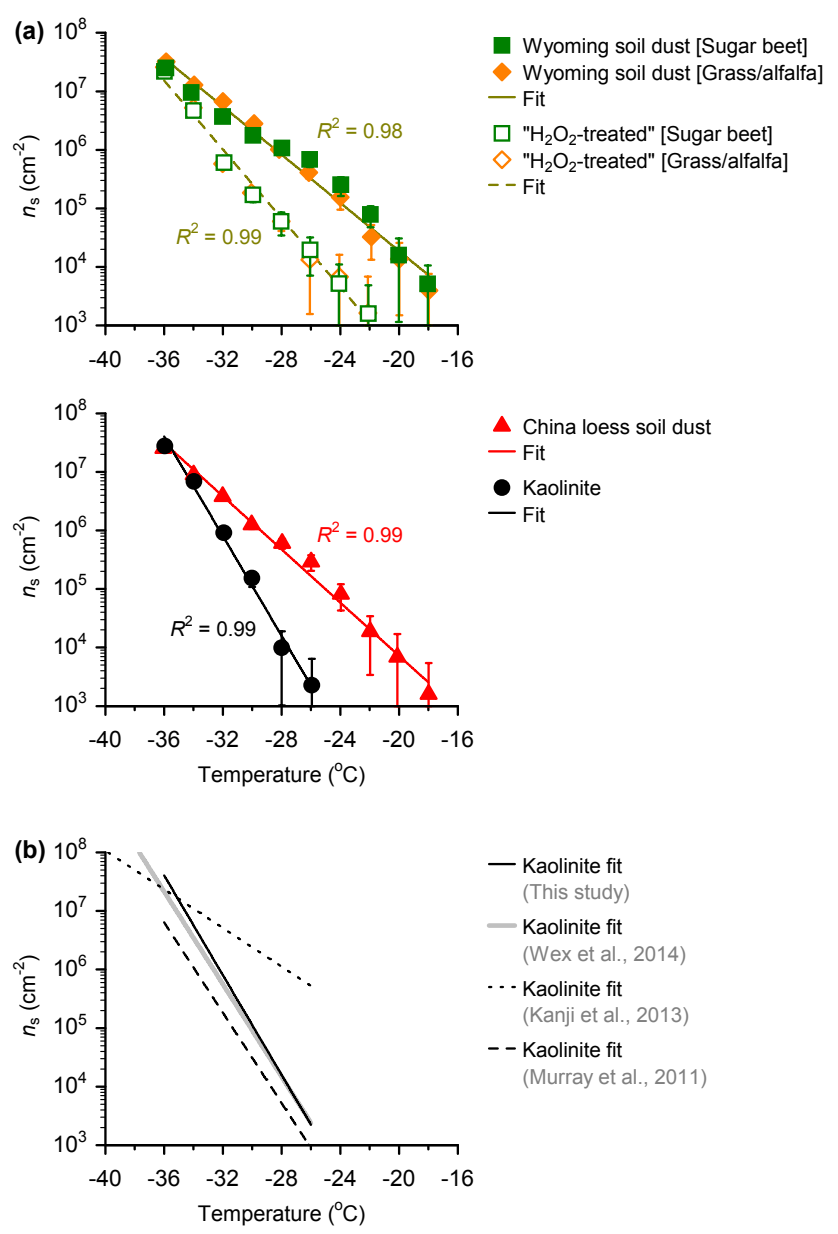

Figure A1. Fit to ice-nucleation active site densities for various dusts. (a) Parameterizations of $n_{\mathrm{S}}$ for untreated agricultural soil dusts $\left(\ln \left(n_{\mathrm{S}}\right)=-0.4736 T+0.3644\right.$; validity range: $\quad-36^{\circ} \mathrm{C}<T<-18{ }^{\circ} \mathrm{C}$ ) and for $\mathrm{H}_{2} \mathrm{O}_{2}$-treated agricultural soil dusts $\left(\ln \left(n_{\mathrm{S}}\right)=-0.6773 T-7.8436\right.$; validity range: $\left.-36^{\circ} \mathrm{C}<T<-22^{\circ} \mathrm{C}\right)$. Parameterizations of $n_{\mathrm{s}}$ for untreated China loess soil dust $\left(\ln \left(n_{\mathrm{S}}\right)=-0.5230 T-1.5767\right.$; validity range: $-36{ }^{\circ} \mathrm{C}<T<-18{ }^{\circ} \mathrm{C}$ ) and for untreated kaolinite $\quad\left(\ln \left(n_{\mathrm{S}}\right)=-0.9803 T-17.7764 ; \quad\right.$ validity range: $-36{ }^{\circ} \mathrm{C}<T<-26{ }^{\circ} \mathrm{C}$ ) are also shown. Error bars represent standard deviations. (b) Comparison of the $n_{\mathrm{s}}$ parameterizations for kaolinite from this study, Murray et al. (2011), Kanji et al. (2013) and Wex et al. (2014).

IN, $f_{\text {IN [inorganic] }}(T)$ and $f_{\mathrm{IN} \text { [organic] }}(T)$, respectively, can be estimated:

$f_{\mathrm{IN} \text { [inorganic] }}(T)=\frac{N_{\mathrm{IN} \text { [inorganic] }}(T)}{N_{\mathrm{IN} \text { [agri. soildust] }}(T)}$,

$f_{\mathrm{IN} \text { [organic] }}(T)=1-f_{\mathrm{IN} \text { [inorganic] }}(T)$.

\section{A2 Estimation of the number concentrations of ice nuclei of agricultural soil origin}

Here, we describe a possible method to estimate the global mean number concentrations of IN of agricultural soil origin under mixed-phase cloud conditions as shown in Fig. 6. According to modeling estimates, the zonal annual mean number concentrations of soil dusts $(1 \mu \mathrm{m}$ in diameter) at the $600 \mathrm{hPa}$ pressure altitude range from 0.1 to $50 \mathrm{~cm}^{-3}$ (Hoose et al., 2010; Murray et al., 2012). If soil dusts in the global atmosphere can be regarded as consisting of only desert and agricultural soil dusts, then the zonal annual mean concentration of soil dusts, $N_{\text {total [soil dust] }}\left(=0.1\right.$ to $\left.50 \mathrm{~cm}^{-3}\right)$, may be expressed as

$$
\begin{aligned}
& N_{\text {total [soildust] }}=N_{\text {total [desert soil dust] }} \\
& \quad+N_{\text {total [agri. soil dust] }},
\end{aligned}
$$

where $N_{\text {total [desert soil dust] }}$ is the number concentration of desert soil dust particles. Recently, Murray et al. (2012) estimated the zonal annual mean number concentration of IN of desert soil origin, $N_{\mathrm{IN}}$ [desert soil dust] $(T)$, using the formula

$$
\begin{gathered}
N_{\mathrm{IN} \text { [desert soildust] }}(T)=N_{\text {total [desert soil dust] }} \\
\quad\left(1-\exp \left(-n_{\mathrm{s} \text { [desert soil dust] }}(T) s\right)\right)
\end{gathered}
$$

where $n_{\mathrm{s}}$ [desert soil dust] $(T)$ is the $n_{\mathrm{s}}$ value for desert soil dusts (Niemand et al., 2012). In this calculation, Murray et al. (2012) assumed that all dusts are of desert origin (i.e., $N_{\text {total [desert soil dust] }}: N_{\text {total [agri. soil dust] }}=100: 0$ ). The results are shown in Fig. 6a. However, in Fig. 6b, we provide two estimates of the global mean number concentrations of both desert and agricultural soil dust IN by assuming that agricultural soil dusts account for $5 \%\left(N_{\text {total [desert soil dust] : }}\right.$ $\left.N_{\text {total [agri. soil dust] }}=95: 5\right)$ and $25 \%\left(N_{\text {total [desert soil dust] }}\right.$ : $\left.N_{\text {total [agri. soil dust] }}=75: 25\right)$ and by combining Eqs. (A2), (A7) and (A8).

Acknowledgements. We thank Masataka Nishikawa for providing China loess soils; Robert Baumgartner and Jenna Meeks for access to the fields at SAREC; Kazutaka Hara, Atsushi Matsuki and Yasunobu Iwasaka for their support for the preparation of SEM/EDX analysis; Ryan C. Sullivan for his assistance for the setup of dust generation systems. We also thank Naruki Hiranuma for helpful discussions. This research was funded in part by the National Science Foundation (NSF) under grants ATM-0841542, ATM-0841602 and AGS-1036028. Y. Tobo acknowledges the Japan Society for the Promotion of Science (JSPS) Postdoctoral Fellowships for Research Abroad.

Edited by: D. Knopf 


\section{References}

Abbatt, J. P. D., Benz, S., Cziczo, D. J., Kanji, Z., Lohmann, U., and Möhler, O.: Solid ammonium sulfate aerosols as ice nuclei: a pathway for cirrus cloud formation, Science, 313, 1770-1773, 2006.

Atkinson, J. D., Murray, B. J., Woodhouse, M. T., Whale, T. F., Baustian, K. J., Carslaw, K. S., Dobbie, S., O’Sullivan, D., and Malkin, T. L.: The importance of feldspar for ice nucleation by mineral dust in mixed-phase clouds, Nature, 498, 355-358, 2013.

Augustin, S., Wex, H., Niedermeier, D., Pummer, B., Grothe, H., Hartmann, S., Tomsche, L., Clauss, T., Voigtländer, J., Ignatius, K., and Stratmann, F.: Immersion freezing of birch pollen washing water, Atmos. Chem. Phys., 13, 10989-11003, doi:10.5194/acp-13-10989-2013, 2013.

Chipera, S. J. and Bish, D. L.: Baseline studies of the clay minerals society source clays: powder X-ray diffraction analyses, Clays and Clay Minerals, 49, 398-409, 2001.

Christner, B. C., Morris, C. E., Foreman, C. M., Cai, R., and Sands, D. C.: Ubiquity of biological ice nucleators in snowfall, Science, 319, 1214-1214, 2008.

Conen, F., Morris, C. E., Leifeld, J., Yakutin, M. V., and Alewell, C.: Biological residues define the ice nucleation properties of soil dust, Atmos. Chem. Phys., 11, 9643-9648, doi:10.5194/acp-119643-2011, 2011.

Creamean, J. M., Suski, K. J., Rosenfeld, D., Cazorla, A., DeMott, P. J., Sullivan, R. C., White, A. B., Ralph, F. M., Minnis, P., Comstock, J. M., Tomlinson, J. M., and Prather, K. A.: Dust and biological aerosols from the Sahara and Asia influence precipitation in the western U. S., Science, 339, 1572-1578, 2013.

Cziczo, D. J., Froyd, K. D., Hoose, C., Jensen, E. J., Diao, M., Zondlo, M. A., Smith, J. B., Twohy, C. H., and Murphy, D. M.: Clarifying the dominant sources and mechanisms of cirrus cloud formation, Science, 340, 1320-1324, 2013.

DeMott, P. J., Cziczo, D. J., Prenni, A. J., Murphy, D. M., Kreidenweis, S. M., Thomson, D. S., Borys, R., and Rogers, D. C.: Measurements of the concentration and composition of nuclei for cirrus formation, Proc. Natl. Acad. Sci. USA, 100, 14655-14660, 2003.

Fernández, I., Cabaneiro, A., and Carballas, T.: Organic matter changes immediately after a wildfire in an Atlantic forest soil and comparison with laboratory soil heating, Soil Biol. Biochem., 29, $1-11,1997$.

Formenti, P., Schütz, L., Balkanski, Y., Desboeufs, K., Ebert, M., Kandler, K., Petzold, A., Scheuvens, D., Weinbruch, S., and Zhang, D.: Recent progress in understanding physical and chemical properties of African and Asian mineral dust, Atmos. Chem. Phys., 11, 8231-8256, doi:10.5194/acp-11-8231-2011, 2011.

Fornea, A. P., Brooks, S. D., Dooley, J. B., and Saha, A.: Heterogeneous freezing of ice on atmospheric aerosols containing ash, soot, and soil, J. Geophys. Res., 114, D13201, doi:10.1029/2009JD011958, 2009.

Forster, P., Ramaswamy, V., Artaxo, P., Berntsen, T., Betts, R., Fahey, D. W., Haywood, J., Lean, J., Lowe, D. C., Myhre, G., Nganga, J., Prinn, R., Raga, G., Schulz, M., and Van Dorland, R.: Changes in atmospheric constituents and in radiative forcing, in: Climate Change 2007: The Physical Science Basis, Contribution of Working Group I to the Fourth Assessment Report of the International Panel on Climate Change, edited by: Solomon, S. Qin, D., Manning, M., Chen, Z., Marquis, M., Averyt, K. B.,
Tignor, M., and Miller, H. L., Cambridge University Press, Cambridge, UK and New York, NY, USA, 129-234, 2007.

Ginoux, P., Prospero, J. M., Gill, T. E., Hsu, N. C., and Zhao, M.: Global-scale attribution of anthropogenic and natural dust sources and their emission rates based on MODIS Deep Blue aerosol products, Rev. Geophys., 50, RG3005, doi:10.1029/2012RG000388, 2012.

Hartmann, S., Augustin, S., Clauss, T., Wex, H., Šantl-Temkiv, T., Voigtländer, J., Niedermeier, D., and Stratmann, F.: Immersion freezing of ice nucleation active protein complexes, Atmos. Chem. Phys., 13, 5751-5766, doi:10.5194/acp-13-57512013, 2013.

Hill, T. C. J., DeMott, P. J., Tobo, Y., Fröhlich-Nowoisky, J., Stump, W. L., and Franc, G. D.: Hunting the snark: identifying the organic ice nuclei in soils, AIP Conf. Proc., 1527, 910-913, doi:10.1063/1.4803419, 2013.

Hiranuma, N., Möhler, O., Yamashita, K., Tajiri, T., Saito, A., Kiselev, A., Hoose, C., and Murakami, M.: Ice nucleation by cellulose and its potential impact on clouds and climate, Geophys. Res. Abs., 16, EGU2014-10881-2, 2014.

Hoose, C. and Möhler, O.: Heterogeneous ice nucleation on atmospheric aerosols: a review of results from laboratory experiments, Atmos. Chem. Phys., 12, 9817-9854, doi:10.5194/acp-12-98172012, 2012.

Hoose, C., Kristjánsson, J. E., Chen, J.-P., and Hazra, A.: Classicaltheory-based parameterization of heterogeneous ice nucleation by mineral dust, soot, and biological particles in a global climate model, J. Atmos. Sci., 67, 2483-2503, 2010.

Iannone, R., Chernoff, D. I., Pringle, A., Martin, S. T., and Bertram, A. K.: The ice nucleation ability of one of the most abundant types of fungal spores found in the atmosphere, Atmos. Chem. Phys., 11, 1191-1201, doi:10.5194/acp-11-1191-2011, 2011.

Kanji, Z. A., Welti, A., Chou, C., Stetzer, O., and Lohmann, U.: Laboratory studies of immersion and deposition mode ice nucleation of ozone aged mineral dust particles, Atmos. Chem. Phys. 13, 9097-9118, doi:10.5194/acp-13-9097-2013, 2013.

Knopf, D. A. and Alpert, P. A.: A water activity based model of heterogeneous ice nucleation kinetics for freezing of water and aqueous solution droplets, Faraday Discuss., 165, 513-534, 2013.

Knopf, D. A., Wang, B., Laskin, A., Moffet, R. C., and Gilles, M. K.: Heterogeneous nucleation of ice on anthropogenic organic particles collected in Mexico City, Geophys. Res. Lett., 37, L11803, doi:10.1029/2010GL043362, 2010.

Kok, J. F.: A scaling theory for the size distribution of emitted dust aerosols suggests climate models underestimate the size of the global dust cycle, Proc. Natl. Acad. Sci. USA, 108, 1016-1021, 2011.

Koop, T., Luo, B., Tsias, A., and Peter, T.: Water activity as the determinant for homogeneous ice nucleation in aqueous solutions, Nature, 406, 611-614, 2000.

Laskin, A. and Cowin, J. P.: Automated single-particle SEM/EDX analysis of submicrometer particles down to $0.1 \mu \mathrm{m}$, Anal Chem., 73, 1023-1029, 2001.

Mahowald, N. M., Rivera, G. D. R., and Luo, C.: Comment on "Relative importance of climate and land use in determining present and future soil dust emission" by I. Tegen et al., Geophys. Res. Lett., 31, L24105, doi:10.1029/2004GL021272, 2004 
Matsuki, A., Quennehen, B., Schwarzenboeck, A., Crumeyrolle, S., Venzac, H., Laj, P., and Gomes, L.: Temporal and vertical variations of aerosol physical and chemical properties over West Africa: AMMA aircraft campaign in summer 2006, Atmos. Chem. Phys., 10, 8437-8451, doi:10.5194/acp-10-84372010, 2010a.

Matsuki, A., Schwarzenboeck, A., Venzac, H., Laj, P., Crumeyrolle, S., and Gomes, L.: Cloud processing of mineral dust: direct comparison of cloud residual and clear sky particles during AMMA aircraft campaign in summer 2006, Atmos. Chem. Phys., 10, 1057-1069, doi:10.5194/acp-10-1057-2010, 2010b.

Murray, B. J., Wilson, T. W., Dobbie, S., Cui, Z., Al-Jumur, S. M. R. K., Möhler, O., Schnaiter, M., Wagner, R., Benz, S., Niemand, M., Saathoff, H., Ebert, V., Wagner, S., and Kärcher, B.: Heterogeneous nucleation of ice particles on glassy aerosols under cirrus conditions, Nat. Geosci., 3, 233-237, 2010.

Murray, B. J., Broadley, S. L., Wilson, T. W., Atkinson, J. D., and Wills, R. H.: Heterogeneous freezing of water droplets containing kaolinite particles, Atmos. Chem. Phys., 11, 4191-4207, doi:10.5194/acp-11-4191-2011, 2011

Murray, B. J., O’Sullivan, D., Atkinson, J. D., and Web, M. E.: Ice nucleation by particles immersed in supercooled cloud droplets, Chem. Soc. Rev., 41, 6519-6554, 2012.

Niemand, M., Möhler, O., Vogel, B., Vogel, H., Hoose, C., Connolly, P., Klein, H., Bingemer, H., DeMott, P., Skrotzki, J., and Leisner, T.: A particle-surface-area-based parameterization of immersion freezing on desert dust particles, J. Atmos. Sci., 69, 3077-3092, 2012.

Nickovic, S., Vukovic, A., Vujadinovic, M., Djurdjevic, V., and Pejanovic, G.: Technical Note: High-resolution mineralogical database of dust-productive soils for atmospheric dust modeling, Atmos. Chem. Phys., 12, 845-855, doi:10.5194/acp-12-8452012, 2012.

Nishikawa, M., Hao, Q., and Morita, M.: Preparation and evaluation of certified reference materials for Asian mineral dust, Global Environ. Res., 4, 103-113, 2000.

O’Sullivan, D., Murray, B. J., Malkin, T. L., Whale, T. F., Umo, N. S., Atkinson, J. D., Price, H. C., Baustian, K. J., Browse, J., and Webb, M. E.: Ice nucleation by fertile soil dusts: relative importance of mineral and biogenic components, Atmos. Chem. Phys., 14, 1853-1867, doi:10.5194/acp-14-1853-2014, 2014.

Paul, E. A. (Ed.): Soil microbiology, ecology, and biochemistry, Academic Press, Oxford, UK, 2007.

Pósfai, M., Li, J., Anderson, J. R., and Buseck, P. R.: Aerosol bacteria over the South Ocean during ACE-1, Atmos. Res., 66, 231240, 2003.

Pratt, K. A., DeMott, P. J., French, J. R., Wang, Z., Westphal, D. L., Heymsfield, A. J., Twohy, C. H., Prenni, A. J., and Prather, K. A.: In situ detection of biological particles in cloud ice-crystals, Nat. Geosci., 2, 398-401, 2009.

Prenni, A. J., Tobo, Y., Garcia, E., DeMott, P. J., Huffman, J. A., McCluskey, C. S., Kreidenweis, S. M., Prenni, J. E., Pöhlker, C., and Pöschl, U.: The impact of rain on ice nuclei populations at a forested site in Colorado, Geophys. Res. Lett., 40, 227-231, 2013.

Pruppacher, H. R. and Klett, J. D.: Microphysics of clouds and precipitation, Kluwer Academic Publishers, Dordrecht, the Netherlands, 1997.
Pummer, B. G., Bauer, H., Bernardi, J., Bleicher, S., and Grothe, H.: Suspendable macromolecules are responsible for ice nucleation activity of birch and conifer pollen, Atmos. Chem. Phys., 12, 2541-2550, doi:10.5194/acp-12-2541-2012, 2012.

Richardson, M. S., DeMott, P. J., Kreidenweis, S. M., Cziczo, D. J., Dunlea, E. J., Jimenez, J. L., Thomson, D. S., Ashbaugh, L. L., Borys, R. D., Westphal, D. L., Casuccio, G. S., and Lersch, T. L.: Measurements of heterogeneous ice nuclei in the western United State in springtime and their relation to aerosol characteristics, J. Geophys. Res., 112, D02209, doi:10.1029/2006JD007500, 2007.

Rigg, Y. J., Alpert, P. A., and Knopf, D. A.: Immersion freezing of water and aqueous ammonium sulfate droplets initiated by humic-like substances as a function of water activity, Atmos. Chem. Phys., 13, 6603-6622, doi:10.5194/acp-13-6603-2013, 2013.

Rogers, D. C., DeMott, P. J., Kreidenweis, S. M., and Chen, Y.: A continuous-flow diffusion chamber for airborn measurements of ice nuclei, J. Atmos. Oceanic Technol., 18, 725-741, 2001.

Šantl-Temkiv, T., Finster, K., Dittmar, T., Hansen, B. M., Thyrhaug, R., Nielsen, N. W., and Karlson, U. G.: Hailstones: a window into the microbial and chemical inventory of a storm cloud, PLoS ONE, 8, e53550, doi:10.1371/journal.pone.0053550, 2013.

Schnell, R. C. and Vali, G.: Atmospheric ice nuclei from decomposing vegetation, Nature, 236, 163-165, 1972.

Sullivan, R. C., Miñambres, L., DeMott, P. J., Prenni, A. J., Carrico, C. M., Levin, E. J. T., and Kreidenweis, S. M.: Chemical processing does not always impair heterogeneous ice nucleation of mineral dust particles, Geophys. Res. Lett., 37, L24805, doi:10.1029/2010GL045540, 2010a.

Sullivan, R. C., Petters, M. D., DeMott, P. J., Kreidenweis, S. M., Wex, H., Niedermeier, D., Hartmann, S., Clauss, T., Stratmann, F., Reitz, P., Schneider, J., and Sierau, B.: Irreversible loss of ice nucleation active sites in mineral dust particles caused by sulphuric acid condensation, Atmos. Chem. Phys., 10, 1147111487, doi:10.5194/acp-10-11471-2010, 2010 b.

Szyrmer, W. and Zawadzki, I.: Biogenic and anthropogenic sources of ice-forming nuclei: a review, Bull. Am. Meteorol. Soc., 78, 209-228, 1997.

Tegen, I., Werner, M., Harrison, S. P., and Kohfeld, K. E.: Relative importance of climate and land use in determining present and future global soil dust emission, Geophys. Res. Lett., 31, L05105, doi:10.1029/2003GL019216, 2004.

Tobo, Y., Zhang, D., Matsuki, A., and Iwasaka, Y.: Asian dust particles converted into aqueous droplets under remote marine atmospheric conditions, Proc. Natl. Acad. Sci. USA, 107, 1790517910, 2010.

Tobo, Y., DeMott, P. J., Raddatz, M., Niedermeier, D., Hartmann, S., Kreidenweis, S. M., Stratmann, F., and Wex, H.: Impacts of chemical reactivity on ice nucleation of kaolinite particles: a case study of levoglucosan and sulfuric acid, Geophys. Res. Lett., 39, L19803, doi:10.1029/2012GL053007, 2012.

Tobo, Y., Prenni, A. J., DeMott, P. J., Huffman, A. J., McCluskey, C. S., Tian, G., Pöhlker, C., Pöschl, U., and Kreidenweis, S. M.: Biological aerosol particles as a key determinant of ice nuclei populations in a forest ecosystem, J. Geophys. Res.-Atmos., 118, 10100-10110, 2013.

Wang, B. and Knopf, D. A.: Heterogeneous ice nucleation on particles composed of humic-like substances impacted by $\mathrm{O}_{3}$, J. Geophys. Res., 116, D03205, doi:10.1029/2010JD014964, 2011. 
Wang, B., Lambe, A. T., Massoli, P., Onasch, T. B., Davidovits, P., Worsnop, D. R., and Knopf, D. A.: The deposition ice nucleation and immersion freezing potential of amorphous secondary organic aerosol: pathways for ice and mixed-phase cloud formation, J. Geophys. Res., 117, D16209, doi:10.1029/2012JD018063, 2012a.

Wang, B., Laskin, A., Roedel, T., Gilles, M. K., Moffet, R. C., Tivanski, A. V., and Knopf, D. A.: Heterogeneous ice nucleation and water uptake by field-collected atmospheric particles below 273 K, J. Geophys. Res., 117, D00V19, doi:10.1029/2012JD017446, 2012b.
Wex, H., DeMott, P. J., Tobo, Y., Hartmann, S., Rösch, M., Clauss, T., Tomsche, L., Niedermeier, D., and Stratmann, F.: Kaolinite particles as ice nuclei: learning from the use of different kaolinite samples and different coatings, Atmos. Chem. Phys., 14, 55295546, doi:10.5194/acp-14-5529-2014, 2014. 